\title{
Comparison between gas chromatography and high- performance liquid chromatography analysis of the reaction products formed by the hydroxylation of phenol
}

\section{Citation for published version (APA):}

vd Pol, A. J. H. P., Verduijn, A. J., \& Hooff, van, J. H. C. (1993). Comparison between gas chromatography and high-performance liquid chromatography analysis of the reaction products formed by the hydroxylation of phenol. Applied Catalysis. A, General, 96(2), L13-L20. https://doi.org/10.1016/0926-860X(90)80003-W

DOI:

10.1016/0926-860X(90)80003-W

Document status and date:

Published: 01/01/1993

\section{Document Version:}

Publisher's PDF, also known as Version of Record (includes final page, issue and volume numbers)

\section{Please check the document version of this publication:}

- A submitted manuscript is the version of the article upon submission and before peer-review. There can be important differences between the submitted version and the official published version of record. People interested in the research are advised to contact the author for the final version of the publication, or visit the DOI to the publisher's website.

- The final author version and the galley proof are versions of the publication after peer review.

- The final published version features the final layout of the paper including the volume, issue and page numbers.

Link to publication

\footnotetext{
General rights

- You may freely distribute the URL identifying the publication in the public portal. follow below link for the End User Agreement:

www.tue.nl/taverne

\section{Take down policy}

If you believe that this document breaches copyright please contact us at:

openaccess@tue.nl

providing details and we will investigate your claim.
}

Copyright and moral rights for the publications made accessible in the public portal are retained by the authors and/or other copyright owners and it is a condition of accessing publications that users recognise and abide by the legal requirements associated with these rights.

- Users may download and print one copy of any publication from the public portal for the purpose of private study or research.

- You may not further distribute the material or use it for any profit-making activity or commercial gain

If the publication is distributed under the terms of Article $25 \mathrm{fa}$ of the Dutch Copyright Act, indicated by the "Taverne" license above, please 
Comparison between gas chromatography and high-performance liquid chromatography analysis of the reaction products formed by the hydroxylation of phenol

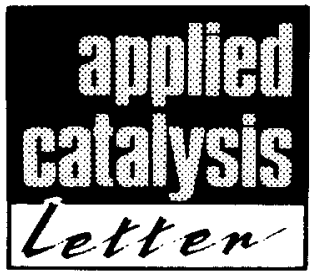

\title{
A.J.H.P. van der Pol, A.J. Verduyn and J.H.C. van Hooff
}

Schuit Institute of Catalysis, Eindhoven University of Technology, P.O. Box 513, 5600 MB Eindhoven (Netherlands)

(Received 8 December 1992, revised manuscript received 18 December 1992)

\begin{abstract}
Gas-chromatographic (GC) analysis of reaction mixtures containing hydrogen peroxide show high concentrations of paraquinone, while only small amounts are observed by high performance liquid chromatography (HPLC). The probable explanation for this discrepancy is the occurrence of a reaction of hydroquinone with hydrogen peroxide during GC analysis. The general conclusion is that HPLC analysis is the preferred technique to analyze the reaction products as long as hydrogen peroxide is present in the samples.
\end{abstract}

Keywords: GC analysis; HPLC analysis; hydroxylation of phenol; phenol hydroxylation; titanium silicalite 1; TS-1

\section{INTRODUCTION}

In recent literature [1-8] much attention has been paid to the hydroxylation of phenol with hydrogen peroxide over titanium silicalite 1 (TS-1). All authors report the selective formation of hydroquinone and catechol at the end of the reaction, while some authors also report the formation of considerable amounts of paraquinone at the initial stage of the reaction. Most of these results are obtained by gas chromatography (GC) analysis of the reaction products [37]. When comparing GC and high-performance liquid chromatography (HPLC) analysis we, however, observed important differences, especially con-

Correspondence to: Dr. A.J.H.P. van der Pol, Schuit Institute of Catalysis, Eindhoven University of Technology, P.O. Box 513, 5600 MB Eindhoven, Netherlands. Tel. (+31-40)474952, fax. (+3140) 455054 . 
cerning the paraquinone formation. For this reason we investigated extensively these two analysis methods on their suitability for the analysis of the reaction products of the hydroxylation of phenol with hydrogen peroxide.

\section{EXPERIMENTAL}

All chemicals, hydroquinone ( $>99 \%$ ), catechol (99\%), paraquinone (98\%), phenol $(99.5 \%)$, acetone ( $>97 \%$ ) and hydrogen peroxide ( $35 \mathrm{wt} . \%$ ) were obtained from Merck. Purity was checked by GC and HPLC analysis.

The catalyst used was TS-1, with a Si/Ti mole ratio of 35 and a crystallite size of $0.2 \mu \mathrm{m}$. Details of the synthesis and characterization have already been reported elsewhere [9].

The hydroxylation reaction was performed in a $100-\mathrm{ml}$ stirred batch reactor using $10 \mathrm{~g}$ phenol, $10 \mathrm{ml}$ acetone and $0.25 \mathrm{~g}$ of TS-1 catalyst, under reflux conditions (about $80^{\circ} \mathrm{C}$ ). At the beginning of the reaction $2 \mathrm{ml}$ of a $35 \mathrm{wt} . \%$ hydrogen peroxide solution was added to the reaction mixture. A second dose of $2 \mathrm{ml} 35 \mathrm{wt} .-\%$ hydrogen peroxide was added when the hydrogen peroxide conversion reached more than $95 \%$. The course of the reaction was followed

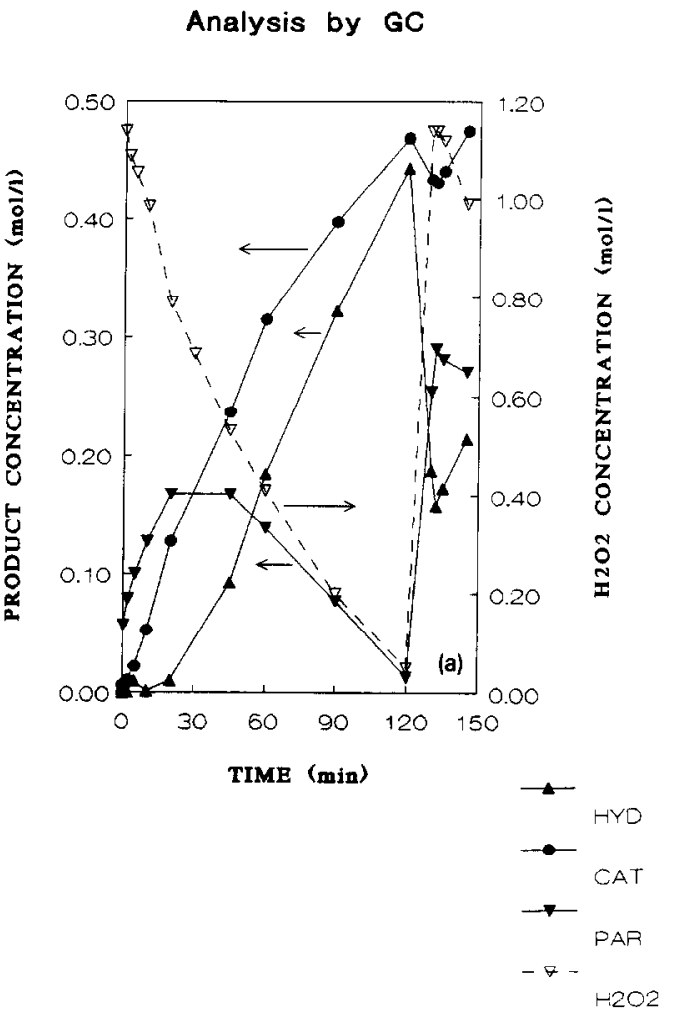


by taking small samples (less than $0.5 \mathrm{ml}$ ) at time intervals of between 2 and $30 \mathrm{~min}$. The samples were filtered to remove the catalyst and cooled in ice.

Homogeneous reactions of hydroquinone and catechol with hydrogen peroxide (without catalyst) were performed in the same 100-ml stirred reactor; as solvent a $10 \mathrm{~g}$ phenol, $10 \mathrm{ml}$ acetone mixture was used. The samples were taken within $1 \mathrm{~min}$ of the addition of hydrogen peroxide, and cooled in ice.

For GC analysis the samples were injected without any pretreatment. The samples for HPLC analysis were diluted 1000 times in water.

For GC analysis a 6000 VEGA series 2 GC with autosampler, from Carlo Erba, equipped with a capillary DB-1 column was used. The injection temperature was $280^{\circ} \mathrm{C}$, the column temperature was $140^{\circ} \mathrm{C}$ and the detector temperature was $250^{\circ} \mathrm{C}$. For HPLC analysis a Milton Roy CM4000 multiple solvent delivery system was used with a SM4000 dual wavelength UV detector (used simultaneously at 220 and $243 \mathrm{~nm}$ ). A Marathon autosampler was used to inject the samples on a RP-18 column (Chrompack) of $25 \mathrm{~cm}$. The column

Analysis by HPLC

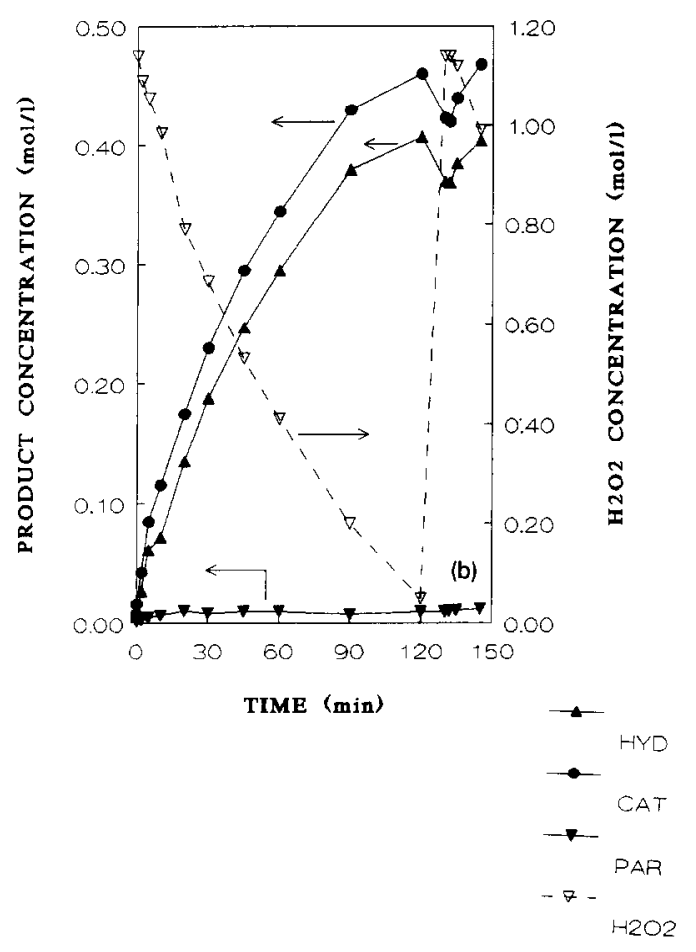

Fig. 1. Analysis of reaction products of the hydroxylation of phenol with TS-1. After about 120 min, $2 \mathrm{ml}$ hydrogen peroxide was added. $\mathrm{HYD}=$ Hydroquinone, CAT $=$ Catechol and PAR = paraquinone. (a) Analysis by GC, (b) analysis by HPLC. 
temperature was $30^{\circ} \mathrm{C}$ and a methanol/water mixture $(10 / 90$ vol.- $\%, 1 \mathrm{ml}$ per min) was used as the solvent.

The decrease of the hydrogen peroxide concentration was followed by standard iodometric titration.

\section{RESULTS AND DISCUSSION}

A comparison of the course of the reaction for the hydroxylation of phenol, as analyzed with GC and HPLC is shown in Fig. 1a and b. Both products and hydrogen peroxide concentrations are given in these figures; it is clear that GC and HPLC data are quit different.

GC analysis (see Fig. 1a) shows a high paraquinone concentration in the first part of the reaction. A S-shaped curve is measured for the hydroquinone concentration. For the catechol concentration the S-shape is less pronounced.

If a second dose of hydrogen peroxide is added (after about $120 \mathrm{~min}$ ) the hydroquinone concentration decreases sharply. Simultaneously, the paraquinone concentration sharply increases. These data suggest that most of the paraquinone is formed instantaneously from hydroquinone. The small decrease in the catechol concentration is mainly due to the dilution effect, caused by the addition of hydrogen peroxide. So catechol seems to be less reactive.

The high paraquinone concentration at the beginning of the reaction and the S-shape of the hydroquinone and catechol curves are absent in the HPLC analysis data (see Fig. 1b). The paraquinone concentration is low during the whole course of the reaction and is not influenced by extra hydrogen peroxide addition. The small decrease of the catechol and hydroquinone concentration after the second hydrogen peroxide addition is due to the dilution effect.

From the above described differences it appears that the two analysis techniques become only comparable when the hydrogen peroxide concentration is low (between $t=100$ and $120 \mathrm{~min}$ ).

To investigate the observed differences further, some additional homogeneous experiments were done. Special attention was paid to the different behaviour of hydroquinone and catechol in the presence of hydrogen peroxide.

Different amounts of hydrogen peroxide were added to a solution of hydroquinone, and a mixture of hydroquinone and catechol in acetone/phenol. Al-

Fig. 2. Analysis of the reaction products of the homogeneous reactions in phenol/acetone mixture $(10 \mathrm{~g} / 10 \mathrm{ml})$ at $80^{\circ} \mathrm{C}$. Exp. 1: $0.25 \mathrm{~mol} / 1$ hydroquinone and $0 \mathrm{~mol} / \mathrm{l}$ hydrogen peroxide; Exp. 2: $0.2 \mathrm{~mol} / 1$ hydroquinone and $1.0 \mathrm{~mol} / 1$ hydrogen peroxide; Exp. 3: $0.2 \mathrm{~mol} / 1$ hydroquinone 0.25 $\mathrm{mol} / \mathrm{l}$, catechol and $0 \mathrm{~mol} / \mathrm{l}$ hydrogen peroxide; Exp. $4: 0.2 \mathrm{~mol} / 1$ hydroquinone, $0.25 \mathrm{~mol} / 1 \mathrm{ca}$ techol and $0.25 \mathrm{~mol} / \mathrm{l}$ hydrogen peroxide; Exp. $5: 0.2 \mathrm{~mol} / \mathrm{l}$ hydroquinone, $0.25 \mathrm{~mol} / \mathrm{l}$ catechol and $0.5 \mathrm{~mol} / 1$ hydrogen peroxide. (a) Analysis by GC, (b) analysis by HPLC. HYD= Hydroquinone, $\mathrm{CAT}=$ Catechol and PAR $=$ paraquinone. 
Analysis by GC

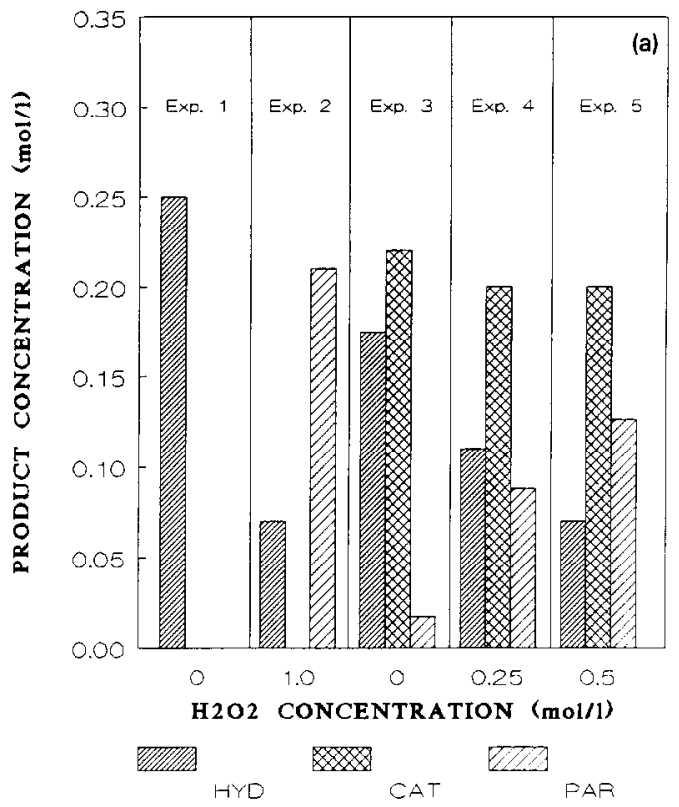

Analysis by HPLC

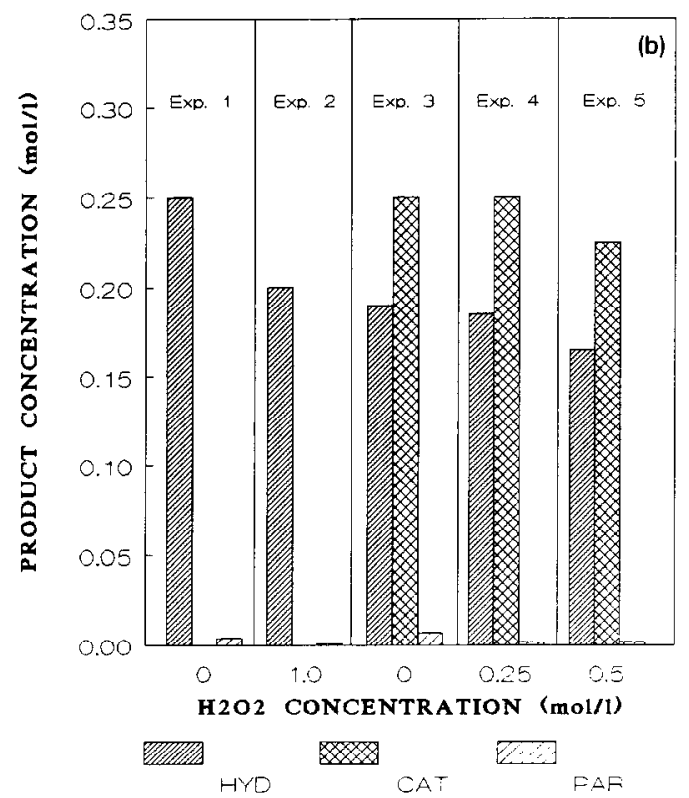


though both oxidized reaction products, paraquinone (yellow) and orthoquinone (red) are strongly coloured, no colour change was observed directly after addition of hydrogen peroxide. Colour changes appeared only, over a time scale of 1-2 $\mathrm{h}$, to yellow for hydroquinone and red/brown for the hydroquinone/ catechol mixture.

Samples taken within $1 \mathrm{~min}$. after addition of hydrogen peroxide were analyzed with GC and HPLC.

GC analysis data (Fig. 2a) of hydroquinone and the hydroquinone catechol mixture suggest that hydroquinone is instantaneously converted to paraquinone. From the results of complementary experiments, as given in Fig. 3, it seems that the conversion of hydroquinone is directly related to the hydrogen peroxide concentration. Catechol seems to be less reactive in the presence of hydrogen peroxide. The product of the consecutive reaction of catechol, orthoquinone, can probably not be detected by GC analysis. It already decomposes at $60-70^{\circ} \mathrm{C}[10]$.

HPLC analysis data as reported in Fig. 2b suggest that further oxidation of hydroquinone and catechol is absent. Conversion of hydroquinone as well as catechol is very low and only small amounts of paraquinone can be observed. Also HPLC analysis does not indicate the formation of orthoquinone.

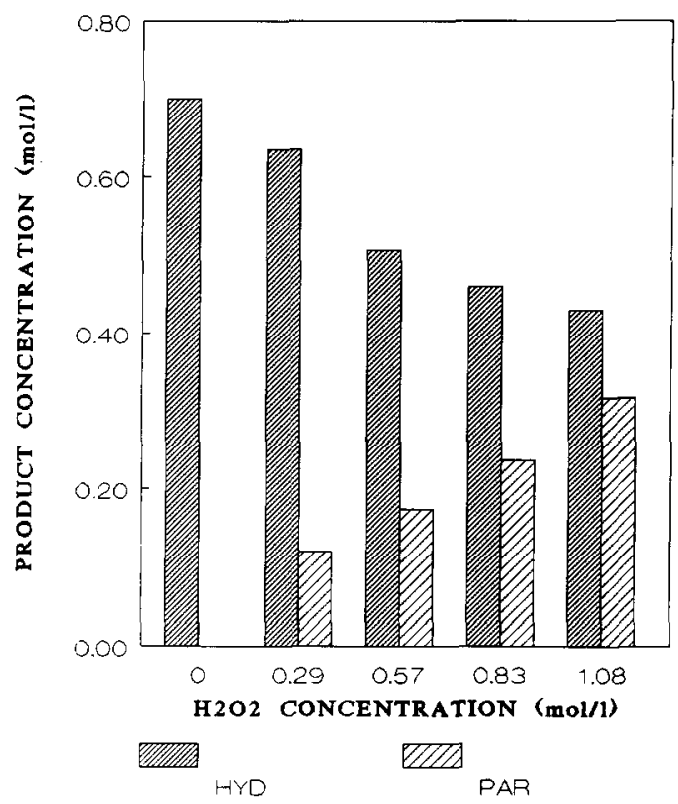

Fig. 3. GC analysis of the products of the homogeneous reaction of hydroquinone with hydrogen peroxide in phenol/acetone mixture $(10 \mathrm{~g} / 10 \mathrm{ml})$ at $80^{\circ} \mathrm{C}$ as a function of hydrogen peroxide concentration. $\mathrm{HYD}=$ Hydroquinone and $\mathrm{PAR}=$ paraquinone. 
Two possible explanations for the observed differences could be the different sample preparation or the different analysis technique.

First the different sample preparation will be discussed.

As already mentioned, GC samples were analyzed without any pretreatment, while HPLC samples were first diluted. So instabilities of the diluted samples could be the reason for the observed differences. However, calibration curves of hydroquinone, catechol, paraquinone and phenol or mixtures of these components stayed the same, with or without hydrogen peroxide present in the samples. Therefore it can be concluded that the sample preparation can not be the cause of the observed differences.

Therefore, the analysis technique itself remains.

In the case of GC analysis, at the high temperatures of the injection port and the GC column, reactions between hydroquinone or catechol and hydrogen peroxide could be possible, while these reactions do not occur under the mild conditions of the HPLC analysis.

This supposition is supported by the fact that no colour change is observed shortly after the addition of hydrogen peroxide to the homogeneous reaction mixtures, while GC analysis already indicates the presence of considerable concentrations of paraquinone.

\section{CONCLUSIONS}

Large differences can be observed between the GC and HPLC analysis of the reaction products of the hydroxylation of phenol with hydrogen peroxide.

In the presence of hydrogen peroxide, high concentrations of paraquinone are detected by GC, while only small amounts of paraquinone can be observed by HPLC.

The probable explanation for this discrepancy is the occurrence of a reaction of hydroquinone with hydrogen peroxide during the GC analysis.

The general conclusion could be that HPLC is the preferred technique to analyze the reaction products of the hydroxylation of phenol as long as hydrogen peroxide is present in the solution.

\section{REFERENCES}

1 M. Taramasso, G. Pegero and B. Notari, US Patent 4410501 (1983).

2 B. Kraushaar-Czarnetzki and J.H.C. van Hooff, Catal. Lett., 2 (1989) 43.

3 J.S. Reddy, R. Kumar and P. Ratnasamy, Appl. Catal., 58 (1990) L1-L4.

4 A. Tuel, S. Moussa-Khouzami, Y. Ben Taarit and C. Naccache, J. Mol. Catal., 68 (1991) 4552.

5 A. Thangaraj, R. Kumar and P. Ratnasamy, J. Catal., 131 (1991) 292-297.

6 D.R.C. Huybrechts, P.L. Buskens and P.A. Jacobs, J. Mol. Catal., 71 (1992) 129-147.

7 J. Sudhakar Reddy, S. Sivasanker and P. Ratnasamy, J. Mol. Catal., 71 (1992) 373-381. 
8 A.J.H.P. van der Pol, A.J. Verduyn and J.H.C. van Hooff, Appl.Catal. A, 92 (2) (1992) 113130.

9 A.J.H.P. van der Pol and J.H.C. van Hooff, Appl. Catal. A, 92(2) (1992) 131-141.

10 R. Willstatter and F. Muller, Ber., 41 (1908) 2580. 